\title{
Analytical study of modular cutting tools dynamic properties
}

\author{
Svetlana Lukina $^{1, *}$, and Margarita Krutyakova $^{1}$ \\ ${ }^{1}$ Moscow polytechnic university, 38 B.Semyonovskaya st., Moscow 107023, Russian Federation
}

\begin{abstract}
The paper studies a comparative evaluation method for the modular cutting tools dynamic properties under the cutting forces loading with the help of the finite element numerical method. The method allows forecasting the modular cutting tool dynamic properties with identification of the confidence bounds for its exploitation in compliance with its intended use and reference operating conditions. The conducted modeling describes the modular cutting tool structure as a ranked set of structural components, such as a frame, a cassette, a cutting insert, etc., oriented towards a certain direction with some surfaces being contiguous and thus making contact interactions. The analytical model is represented by a multi-mass system in the form of elastic rods connected at elastic and damping joints. The research examined different tool structural component layout options, including those equipped/not equipped with a shim, having a radial/tangential (face or peripheral) location type of cutting components. The dynamic compliance values and vibrational modes at the natural frequencies were calculated for all structural component layout options. The calculation results showed an acceptable level of model convergence with the existing experimental data on the cutting tool condition express diagnostics.
\end{abstract}

\section{Introduction}

The relevant task of contemporary production is to enhance machining accuracy and quality while ensuring the established level of operational efficiency [1]. One of the key ways to ensure the necessary machining quality is the use of more progressive cutting tool structures.

The current state and development prospects for metal working is characterized by a broad use of modular cutting tools equipped with indexable cutting inserts which are mechanically clamped and made of hard alloys, ceramics and ultra-hard materials. The following cutting tools with mechanically clamped components are the most widely used ones: straight turning tools, side-facing tools, parting-off tools, boring tools; face and end mills and other tool with standardized principal dimensions [2-4].

A variety of machining situations alongside with underdeveloped calculation methods, unable to solve the problem of a rational tool structure choosing at the design stage, led to emergence of an extensive nomenclature of tools with the same intended uses.

At the moment, several thousands of such cutting tool structures with mechanically clamped cutting components are designed and applied; they differ by their overall dimensions and structural design, the ways cutting components are located and clamped $[5,6]$.

The existing design methods allow for identification of cutting tool geometric and structural parameters while being unable to evaluate a variety of cutting insert locations and clamping ways [7].

Evaluation of the modular cutting tool dynamic properties is a relevant issue for design studies. The modular cutting tool dynamic properties manifest in cutting through the vibration process influencing the tool life and machining accuracy. The approaches for cutting tool dynamic properties forecast referred to in the available literature are based upon experimental express diagnostics and modeling of radially arranged cutting inserts without due regard to their clamping type $[7,8]$.

The objective of our study is to develop the method for a comparative evaluation of cutting tool dynamic properties to identify the best design solutions intended for specific operating conditions.

To achieve the abovementioned objective, the paper sets forth the following research tasks:

- to form and provide an analytical description for the evaluation model of the modular cutting tool dynamic properties with due regard to a variety of cutting insert locations and clamping ways;

- to conduct analytical research of the influence of the modular cutting tool structural component design on the dynamic properties;

- to develop recommendations for application of the modular cutting tool structures with various ways of cutting component location and clamping.

\section{Key provisions of the method for a comparative evaluation of the modular cutting tool dynamic properties}

The developed method is underlain by the assumption that the general modular cutting tool structure defined by a system of design and geometric parameters may be represented as a ranked set of components (elements),

\footnotetext{
* Corresponding author: lukina sv@mail.ru
} 
such as a body, a cassette, a cutting insert, etc., oriented towards a certain direction $[9,10]$. Separate constituents of the tool structural component layout have some contiguous surfaces making contact interactions.

The peculiarities of the component contact surfaces, which have a real geometric contour defined by a set of parameters characterizing their position in relation to the tool coordinates system, dimension and form deviations, its micro relief states, presence of gap clearances (allowances) between these surfaces, are described by a subset of surface nodes $\{\Phi\}$. The subset $\{\Phi\}$ nodes are connected by imaginary lines or surfaces. As a result, the component surfaces are represented as a total of surface elements while their internal structure is represented in the form of a set of finite volume elements. These finite elements are interconnected and interact in the nodes determined by the tool structural component layout; interaction between the components (elements) is determined by the nature of the node connection (rigid, jointed, contact, etc.).

Each tool component is connected with a moving orthogonal coordinates system set in relation to some global system. The node positions are registered as per the coordinates system. The tool component movements and rotations with reference to the coordinates global system are considered as the movements and rotations of surface and finite volume elements connected with local coordinates systems.

To form a geometric element image, the nodes and their associated moving coordinates systems are assigned corresponding movements and rotations traced in relation to the global coordinates system in some certain time periods. To clamp the tool structural layout components in an assigned relative position, the authors introduce a set of rod elements having the stiffness parameters with stochastic or determined characteristics corresponding to the contiguous surface stiffness parameters. The number and the relative location of these rod elements is defined by the tool structural component layout $[11,12]$.

The disturbing action system is explicitly described: the main vector $\{\mathrm{F}\}$ and the main load torque $\{\mathrm{M}\}$ imposed on the tool. The modular cutting tool elastic system is represented by a set of volume, surface and rod finite elements the motion equations of which are described by the Lagrange equations of the second kind and the d'Alembert's principle.

The modular cutting tool dynamic model is represented by the system of differential equations of the form:

$$
[A]\{\ddot{U}\}+[Д]\{\dot{U}\}+[K]\{U\}=\{F\}
$$

where $[\mathrm{A}],[\mathrm{D}]$ are inertia and damping matrices respectively; $\{\mathrm{U}\}$ is a column vector for movements of the finite element nodes; $[\mathrm{K}]$ is a global stiffness matrix for the modular cutting tool structure.

The method was implemented in the software by means of the finite element numerical method.

\section{Implementation of the method for a comparative evaluation of the modular cutting tool dynamic properties}

The developed method was implemented by the example of the design rationale for the modular turning tool and face mill structures. The authors considered four typical clamping and supporting options for a cutting insert: C, $\mathrm{M}, \mathrm{P}, \mathrm{S}$ at radial and tangential (peripheral or face) insert positioning.

Analytical research were conducted to check the capacity and to assess the validity of the developed models by the example of calculation of the structures for modular turning tools and face mills used for machining of medium-carbon steel work pieces $40 \mathrm{X}$ $\left(\mathrm{E}=2 \times 10^{5} \mathrm{MPa}, \mu=0.3\right)$. The taken cutting component (inserts) material was the steel grade $\mathrm{T} 15 \mathrm{~K} 6\left(\mathrm{E}=5.2 \times 10^{5}\right.$ $\mathrm{MPa}, \mu=0.3)$. The clamping and cutting forces varied in the ranges of $50, \ldots, 200 \mathrm{daN}$ and $100, \ldots, 1000 \mathrm{daN}$ respectively.

Harmonic vibrations negatively influencing the tool wear rate and the machining quality represent the tool dynamic system inciting factor. The force vibration impact on the tool dynamic system is expressed through the correspondence of cutting forces along the coordinate axes ""Fig. 1"".
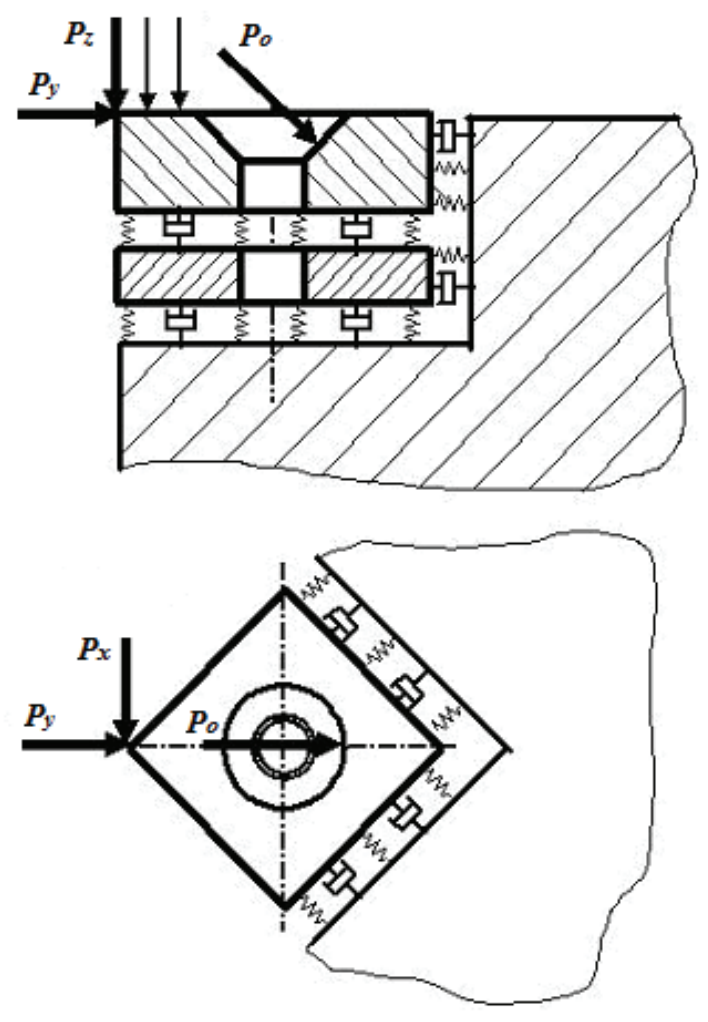

Fig. 1. The analytical model for evaluation of the dynamic properties of the modular face mills with radially located cutting inserts. The S-type clamping.

The calculations resulted in the natural frequencies of the modular cutting tool elastic system and the vibration modes at the modular cutting tool natural frequencies. The validity of the results was evaluated according to the 
correlation of calculated and experimental stiffness values in the reduced mass node points of the tool elastic system; the values of the first vibration natural frequencies; vibration modes at natural frequencies.

Comparison of dynamic properties for different insert positioning options (radial and tangential) demonstrated that, to ensure the minimum wear and to enhance the tool life, it is preferable to choose a radial positioning type (as dynamic compliance values belong to the next lower order in these directions) whereas a tangential positioning type is better for machining quality improvement. When cutting inserts are radially positioned in a low frequency area (up to $3,000 \mathrm{~Hz}$ ) at the first natural frequency of the common elastic system, the modular cutting tool subsystem parameters have a kind of a compensating action which makes the dynamic compliance value $10 \%$ lower towards the normal in relation to the machined surface. Such effect is not observed when the insert is tangentially positioned.

The range of natural frequencies characterizing radially positioned modular mills is shifted towards a high frequency area. Tangentially positioned modular mills have the first mode frequency in the $24-27 \mathrm{kHz}$ range (the range variation is given for various options of the insert clamping), its second mode is in the $42-57 \mathrm{kHz}$ range while the radially positioned tool has the first and the second modes expressed in the ranges of $42-57 \mathrm{kHz}$ and $69-71 \mathrm{kHz}$ respectively. However, the dynamic compliance values towards the maximum wear direction (along the face surface) in the low-frequency area are 1.8 - 2 times lower comparing to the tangentially positioned tool. One can explain the "worse" dynamic properties towards the maximum wear direction of the tool with tangentially positioned inserts basing upon the analysis of modal compliance balances which reflect the contribution of specific components (joints, a cutting component body and a shim body, etc.) into the dynamic compliance value at this mode. Thus, the tool elastic system with tangentially positioned inserts has its joints "cutting insert - shim" and "shim - support of the mill frame seat" "working"; the bodies of the cutting component and the shim undergo elastic deformation at the second mode with a significant impact of the latter factor. In contrast, radially positioned cutting tools generally demonstrate the work of those junction points that are oriented towards coordinate directions in such a manner that the cutting edge top vibration level is lower towards the maximum wear direction. The dynamic compliance level towards the wear direction along the flank is higher for the radial tool, although the priority of this direction is significantly lower in terms of the vibration amplitude influence on the insert wear.

The numerical experiments for evaluation of the modular cutting tool dynamic properties showed that:

- in terms of a better dynamic stiffness towards the maximum tool wear direction along the face surface, the insert clamping options are ranged as follows: $\mathrm{M}, \mathrm{S}, \mathrm{P}$, C;

- all other conditions being equal, the radial option for the cutting insert positioning is more dynamically stiff and provides for the higher tool wear resistance values comparing to the tangential one;
- cutting insert tangential positioning stipulates for the invariability of dynamic properties' values towards the normal as of the machined surface in terms of its clamping;

- cutting insert tangential positioning stipulates for the "work" of not only the joints, but also cutting and support component bodies through all the frequency range of the tool elastic system.

The obtained results allow one to forecast a better machining quality of tangentially positioned modular mills at a high sensitivity to the machining process stability assurance. Therefore, tangential positioning of the cutting inserts is mostly applicable to cutting tools used for finishing operations. To ensure better cutting tool wear resistance and life during roughing operations, it is recommended to position the inserts radially while meeting the requirements towards the frame seat supports, the accuracy of support location and insert clamping regularity. It is necessary to forecast a greater risk of failures for tangentially positioned inserts while in case of radial positioning, one shall foresee the breach of the frame seat due to dynamic vibrations in the modular cutting tool elastic system.

\section{Conclusion}

The research formal results allow forecasting of the modular cutting tool dynamic properties with identification of the confidence bound for their intended use and reference operating conditions, revelation of interrelation between the structural component layout factors and the machining accuracy output parameters at the technical production preparation stage.

This provides the basis for identification of the best solutions for various engineering requirements and limitations as well as for recommendations of the most efficient application of one or another structural component layout under specific operating conditions.

The developed method helps to significantly reduce the scope of conducted modelled and real experiments as it has the purpose of identification and prevention of the wrong cutting tool structure choice at the technical production preparation stage.

The proposed method will be developed as the evaluation of modular cutting tool dynamic properties at high-speed machining $[13,14]$.

\section{References}

1. S. Zivkovic., L.Takic, N.Zivkovic, The improvement of environmental performances by applying ISO 14001 standard - A case study, Chemical Industry and Chemical Engineering Quarterly. vol. 19, № 4, pp. 541-552.( 2013) doi: 10.2298/CICEQ120513088Z

2. A.R. Maslov, Konstruirovanie instrumental'noi osnastki [Construction tooling] (Moscow, Yanus-K Publ., 2012) ISBN 978-5-8037-0557-4

3. V.A. Grechishnikov, S.N. Grigor'ev, S.V. Lukina, Ju.M. Solomencev, A.G. Shirtladze, V.I. Vlasov, 
Processy $i$ operacii formoobrazovanija $i$ instrumental'naja tehnika (Moscow: Janus-K Publ. 280 p., 2006) ISBN 5-8037-0296-X.

4. A.A. Bekaev, Y.V. Maksimov, S.V. Lukina, Predicting the surface quality in discontinuous cutting, Russian Engineering Research. № 35 (10), pp.792 (2015)

5. S.V. Lukina, M.V. Krutyakova Sovremennye problemy organizatsii $i$ upravleniya instrumental'nym obespecheniem mashinostroitel'nykh proizvodstv [Modern problems of organization and management of tool maintenance machine industry] (Moscow, MGTU «MAMI» Publ. 116 p., 2013).

6. S.V. Lukina, Metodika optimizacii proizvodstvennoj dejatel'nosti promyshlennogo predprijatija na osnove kompleksa prognosticheskih reshenij $v$ oblasti vysokotehnologichnyh proizvodstv [The technique of optimizing of the production activity of industrial plant on the basis of a complex of predictive models of formation and selection of design innovative solutions in the field of hightech industries], Vestnik MSTU «STANKIN», №1(32), pp. 125-129 (2015)

7. S.V. Lukina, Povyshenie effektivnosti proektirovaniya sbornogo rezhushchego instrumenta na baze ustanovlennykh vzaimosvyazei konstruktorsko-tekhnologicheskikh

ekonomicheskikh reshenii. Diss. dokt. tekhn. nauk [Improving the efficiency of the design of the cutting tool on the basis of established relationships design and technological and economic decisions. Dr. eng. sci. diss.] (Moscow, 1999)

8. A.S. Yanyushkin, D.V. Lobanov, D.A. Rychkov, Automation of technological preparation of production at selection of cutting tools, J.World of engineering and technology, № 6. p.36-38. (2013)

9. S.V. Lukina, Modelirovanie protsedur formirovaniya $i$ vybora strukturnykh komponovok sbornykh rezhushchikh instrumentov na osnove setevykh graf-modelei [Modeling procedures for formation and choice of structural component layout of modular cutting tools using network graphmodels], Obrabotka metallov (tekhnologiya, oborudovanie, instrumenty) - Metal Working and Material Science, № 2, pp. 28-30 (2009)

10. S.V. Lukina, Avtomatizatsiya protsedur formirovaniya $i$ vybora strukturnykh komponovok sbornykh rezhushchikh instrumentov na etape tekhnicheskoi podgotovki proizvodstva [Automating procedures for formation and choice of structural component layout of modular cutting tools in step of technical preparation production], Vestnik Saratovskogo gosudarstvennogo tekhnicheskogo universiteta - Vestnik Saratov State Technical University, vol. 3, № 1, pp. 241-247 (2011)

11. S.V. Lukina, Modeling of stresses-deformed state of inserted cutting tools during their production and operation, Avtomatizatsiya i Sovremennye Tekhnologii, №4, pp.24 (2001)
12. V.A. Grechishnikov V.A., S.V. Lukina, A.I. Veselov, D.V. Makarov, The forming processes modeling for geometric parameters of inserted cutting tools with regard to their assembly technology, Avtomatizatsiya i Sovremennye Tekhnologii, №4. pp.32 (2001)

13. S.V. Lukina, Otsenka konkurentosposobnosti sbornykh metallorezhushchikh instrumentov na etape ikh proektirovaniya $i$ vybora [Estimation of competitiveness of modular metal-cutting tools at a stage of their designing and a choice], Sborka v mashinostroenii, priborostroenii - Assembling in mechanical engineering and instrument-making, № 9. pp. 3-8 (2011)

14. S.V. Lukina, Formation of the system of the local indicators to assess the quality of the cutting tool at the stage of technical training of production, Obrabotka metallov (tekhnologiya, oborudovanie, instrumenty) - Metal Working and Material Science, № 4(69), p. $43-50 \quad$ (2015) doi: 10.17212/1994-6309-2015-4-43-50 